\title{
ЛІНГВОПОЕТИКА
}

УДК811.161.2`42

Ю. Г. Зайцева

\section{МОВНІ ЗАСОБИ ІНТИМІЗАЦІЇ ПОЕЗІї В ПРОЗІ ІРИНИ ВІЛЬДЕ}

Стаття присвячена розгляду синтаксичних засобів та стилістичних прийомів інтимізації поезії в прозі Ірини Вільде. Здійснено аналіз основних мовних засобів, які допомагають досягнути ефекту зближення авторки з читачем, зокрема акиентовано увагу на інтимізованих звертаннях, імперативі, риторичних питаннях, еліптичних реченнях та парцеляціі. Визначено, щз такі мовні одиниці єчинником творення жанрової специфіки поезії в прозі авторки. Окреслено напрямки подальших наукових досліджень.

Ключові слова: інтимізачія, поезія в прозі, інтимізовані звертання, імператив, риторичні питання, еліптичні речення, парцеляція.

Zaitseva Yu. H. The Language Means of Iryna Wilde's Poetry-in-Prose Intimacy. Sustained interest of the scientists during the late 20th - early 21st century to the study of the author's artistic speech and its impact on the reader, confirms the relevance of the study of linguistic means of intimization. The study of the intimation category has a significant history. The following Ukrainian linguists have dealt with this problem: L. Bulakhovsky, I. Bilodid, M. Karpenko, O. Yaskevych, S. Denysova, A. Koroleva, T. Kosmeda, T. Dekshna, I. Horbach, A. Paliichuk, N. Furist, etc.

Intimation expresses the emotional, expressive and intellectual content of the text, which is associated with creating the communication effect, personal contact of the author with the reader, the performance of a casual conversation between them.

The purpose of this study is to identify the features of the use of language means of intimization for stylistic and semantic organization of poetry texts in prose by Iryna Wilde.

The main language means that help to achieve the rapprochement effect between the author and the reader are analyzed in the article. The attention is focused on intimate conversations, imperatives, rhetorical questions, elliptic sentences, and parceling. Scientific research analysis leads to the conclusion that intimization serves as a means of creating an atmosphere that promotes the formation of feelings such as empathy, compassion and mutual understanding.

The analyzed poetry in Iryna Wilde's prose gives grounds to conclude that the author uses a rich palette of linguistic means of intimization. These means help to achieve the main goal of sincere conversation with the reader, creating a welcoming 
and open atmosphere. The directions of further scientific research which consists in coverage of the other language means of intimization used by the writer are outlined.

Key words: intimacy, poetry-in-prose, intimate appeals, imperative, rhetorical questions, elliptic sentences, parceling.

\section{Вступ}

Зважаючи на антропоцентричний напрям сучасних лінгвістичних досліджень, учені все більшу увагу приділяють вивченню художнього мовлення автора та його впливу на читача (Зайцева, 2015). Стійкий інтерес протягом кінця XX - поч. XXI ст. до цього питання засвідчує актуальність дослідження таких мовних засобів упливу. Серед найбільш ефективних, на нашу думку, можна вважати мовну категорію інтимізації.

Як зазначає А. П. Загнітко, інтимізація - це мовні засоби і прийоми, які передають настрій мовця, наближають автора до читача як до співрозмовника, а також це стилістичний прийом у художньому мовленні, коли автор прагне увійти у ближчий комунікативний контакт з читачем (Загнітко, 2012).

Дослідження категорії інтимізації має значну історію: цією проблемою протягом значного часу займалися такі українські лінгвісти, як Л. Булаховський, І. Білодід, М. Карпенко, О. Яскевич, С. Денисова, А. Корольова, Т. Космеда, Т. Декшна, І. Горбач, А. Палійчук, Н. Фурист та ін.

Академік Л. Булаховський, аналізуючи поезію Т. Шевченка, виділяє чотири основних прийоми інтимізації: «звернення до героїв розповіді як вираження авторського співчуття до того, що вони переживають та думають»; «наказовий спосіб, що запрошує читача подумати, зважити, оцінити повідомлене автором»; «"ми” або форма першої особи дієслова множини»; «уявний діалог між читачем та автором» (Булаховський, 1977).

А. Палійчук виокремлює такі мовні засоби інтимізації, як дейктичні маркери, теперішній час, інтимізовані звертання, імператив, графічні засоби, авторські коментарі, засоби суб'єктивної модальності та оцінки (Палійчук, 2011).

Досліджуючи українські та англійські фольклорні тексти, Н. Фурист виявила основні лексико-словотвірні (лексичні повтори та демінутиви) та граматичні (вказівні частки, неповні речення, інверсійні 
конструкції, звертання та синтаксичні повтори) мовні засоби інтимізації (Фурист, 2011).

Аналіз наукових розвідок дає підстави зробити висновок, що інтимізація слугує прийомом зближення автора з читачем, а також прийомом створення атмосфери, що сприяє формуванню таких почуттів, як співпереживання, співчуття, взаєморозуміння.

Слід зазначити, що дослідження мовних засобів інтимізації поезії в прозі в українській лінгвістиці спеціально не проводилося (відомі дотичні роботи з цієї теми: «Типологія наративних кодів інтимізації в художньому тексті» А. Корольової, «Наративний код інтимізації» (на матеріалах англомовного художнього дискурсу) А. Палійчук, «Лінгвокультурні особливості інтимізації в англійських та українських фольклорних текстах» (на матеріалі казок про тварин) Н. Фурист, «Типологія засобів інтимізації в англомовних і україномовних рекламних текстах» Т. Дейкша), тому ця тема видається актуальною (Зайцева, 2015).

Предметом вивчення в цій статті виступають мовні засоби інтимізації як чинник творення жанрової специфіки поезії в прозі Ірини Вільде.

Мета полягає у виявленні особливостей використання інтимізувальних мовних засобів для стилістичної й семантичної організації текстів поезій в прозі цієї письменниці.

\section{Методи й методики дослідження}

Основним методом дослідження $є$ функціональний метод, який передбачає вивчення мови в процесі функціонування з опертям на прагматичний ефект; у розвідці застосовано також описовий метод, що передбачає інтерпретацію досліджуваних мовних явищ.

\section{Результати та дискусії}

Рання проза Ірини Вільде (Макогон Дарина Дмитрівна) цікава своїм поєднанням реалізму й модерної манери. У творчому доробку мисткині у другій половині $30-$ х років XX століття набуває популярності мала фрагментарна проза, зокрема й поезія в прозі. Мініатюри Ірини Вільде задушевні, емоційнопереконувальні, інтимізовані.

У поезії в прозі письменниця для емоційного зближення з читачем застосовує різноманітні мовні засоби інтимізації. Найбільш 
виразними з-поміж них є, зокрема, риторичні питання, звертання, еліптичні речення, імператив, парцеляція.

У проаналізованих поезіях в прозі Ірини Вільде дієвий засіб інтимізації - інтимізовані звертання. Авторка використовує як прямі, так і непрямі звертання до читача, що робить оповідь інтимною, дуже особистою, напр.: Невже ж ви мали серие, посилаючи іх мені, засудити іх на смерть? (Рожі); У мойй батьківщцні... Але по щьо я буду говорити вам про неї, коли ви не тужите за нею, коли вона для вас така далека й така недійсна? (Моїй Буковині); Гей, молодосте, які сліпі в тебе очі, а як далеко ними бачиш!, Скрипко душі людської, хто тебе настроює так, ио раз твоя музика - правда, якої хіба у бога шукати, а раз -

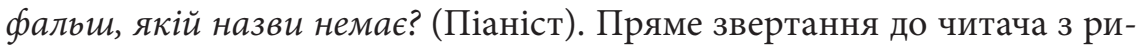
торичним запитанням $є$ індикатором психологічної близькості між співрозмовниками, напр.: Читачу, чи не буває тобі нудно часом?. Але відразу після запитання іде відповідь, таким чином авторка імітує розмову з читачем, що дозволяє зрозуміти авторський задум, робить текст інтимізованим: Тоді розгорни сторінки поеми життя $і$ пошукай той розділ, де змальована людина, схожа на тебе... (Поема життя).

Використання присвійних займенників мій (моя, моє) підсилює інтимізувальний ефект таких звертань, створює певний емоційний відтінок, напр.: Що значить, серие моє, "багато» щзастя?, Може так бути, думко моя?, Що значить ие слово, серие моє?, Чуєш, туго моя? (Всюди однаково). Отже, авторка входить у безпосередній контакт з читачем, викликає певні почуття, думки, допомагає осягнути зміст тексту.

Вживання імператива у поєднанні зі звертанням зменшує психологічну дистанцію між автором та читачем, сприяє атмосфері дружньої розмови. Дієслова, вжиті в наказовому способі, привертають увагу читача, актуалізують, інтимізують спілкування, напр.: Скажи: що має статись тоді, коли за вітриною буде багато весняних жіночих капелюшків?.. (Ти); Будь ласка, сядьте собі проти мене. Що ж ви? не треба так боязко, на самому бережку (Рожі); О, побудь, побудь ше, заблуканий мандрівнику, просять сполочені очі Олени (Подорожній). Вибір дієслова у формі другої особи множини вкажіть мені дозволяє безпосередньо звернутися до читача, але разом з тим, у продовженні речення авторка не вимагає відповіді, а діалогізує оповідь, робить іiі емоційно-експресивною, напр.: Вкажімь мені ви, щзо 
посміхаєтесь з моєї віри, одну-однісіньку жінку, яка не повірила б, що іï вибраний зберіг у своїм любовнім словничку кілька слів виключно для неї, - $і$ перестану вірити у кохання, як не вірю вже у вірність (Ти). Імператив із часткою хай передає швидше побажання авторки, ніж спонукання, що акцентує увагу читача на сказаному, напр.: Хай вступить на подвір'я: пси не гавкають на тих, щь в приязні із панею, Вона звелить запрягти коней, хай відвезуть його на дорогу, звідти вже простісінько до Райкович, Квіти теж потребують нових сил навесні: хай перемішується зужите із свіжим, стара кров землі із молодою (Подорожній).

Таким чином, наказовий спосіб сприяє встановленню контакту між автором та читачем.

Мініатюри Ірини Вільде вирізняються емоційною напругою, що передається великою кількістю риторичних питань, які є дієвим засобом діалогізації мовлення. Вони виконують роль звертання, сприяють підвищенню уваги, залучають до роздумів, таким чином зближуючи автора та читача, інтимізуючи розповідь, напр.: Я думала тоді: як можна вчити когось радості або болю? (Східна мелодія); I звідки раптом така непереможна охота у світ? Хіба вона знає?, Хіба ій не належить трохи світа побачити?, Це все вона дуже добре пам'ятає, але - може, цього замало? Хіба це досить - дати комусь вдосталь хліба й більше не дбати за нього? Чи заспокоєні одні бажання не родять інших - сміливіших? (Пригода Уляни).

Інколи риторичні запитання виступають ніби внутрішнім монологом письменниці, що є емоційно-стилістичним засобом інтимізації, напр.: Яка чіль ї життя? Що ие значить? Чи таке, як вона веде: рівне, обчислене на «сьогодні» $i$ «завтра», чи, може, таке, як иього мандрівника... кожна ніч під іншим небом? (Подорожній); ... що значить, серие моє, «багато» щзастя? Може бути «багато» й «мало» щзастя? Може так бути, думко моя? Що значить ие слово «щастя»? значить ие могти продавати себе тільки за високу иіну? Чи значить ие - могти за гроші купити півсвіту? Навіть те, що непродажне? Чи, може, значить ие - могти нехтувати грішми й жінками? Чи значить ие - вбити в собі тугу за невідомим? Що значить ие слово, серие моє? (Всюди однаково), Хто й яка вона буде, що задля неї забудеш ти мене? Розумна, гарна, молода, з серием чи без нього? I як ти відречешся нашого кохання для спокою серия майбутньої.. Чим уб'єш в їі сериі заздрість 
до наших днів? Скажеш їй, що ти ніколи-ніколи не торкнув устами моїх уст? Запевниш, щзо ти ще нікого так не кохав, якіит.. Чи... може, обіиятимеш, як прийде весна, сказати і ій щзось... чого ти досі ще «ні одній» жінці не говорив? (Ти). Градація таких питально-риторичних речень з використанням вставних слів, звертань, еліптичних речень демонструє внутрішні переживання героїні, яка прагне побороти свій страх перед видуманою можливістю втрати коханого, змушуючи читача замислитися над минущістю, швидкоплинністю часу.

Отже, риторичні питання є активним і продуктивним засобом інтимізації мовлення в поезіях в прозі Ірини Вільде. Вони оживляють текст, створюють умови для спільних з автором роздумів.

У проаналізованих поезіях в прозі поширеним засобом інтимізації є еліптичні речення. Неповні речення створюють діалогічний характер оповіді, що є умовою інтимізації тексту. Саме завдяки еліптичним реченням скорочується дистанція і встановлюється контакт з читачем. На думку Е. Трофімової, неофіційність та невимушеність викладення тексту дозволяють скоротити висловлення, використати лише ті частини речення, які абсолютно необхідні для розуміння змісту читачем (Трофімова, 1981: 35). Такі речення сприяють інтимізації через наближення до розмовного стилю, через вираження різних емоційно-оцінних значень, напр.: Чи не забагато це сказано? Та ні!, Колись вони інакше зустрічали таке сам на сам. Та ба! - ие було колись (Щастя); Ірка, ніхто інший, тільки Ірка знайшла собі дорогу через сад. Так, начебто не було брами. Мчала, мабуть, мов божевільна, бо аж галуззя з вишень поламала. Нерозумний дітвак! (Одного весняного вечора); Потім прийили два важкі роки. Їх буду довго пам'ятати (Східна мелодія). Часто еліптичні речення письменниця використовує для імітації безпосередньої розмови з читачем, ставить запитання або відповідає на уявні репліки читача, напр.: Але раптом поет замовк. Чи втомився? (Поема життя); Власне, вона проти цього нічого не має. Чого? Можна й до університету записатися (Дух часу); Очі твої стали наче більші, наче всевидющі. Що з тобою? Знаєщ, ти вигарніла останніми часами..., Хтось невідомий прислав иілий сніп білих троянд. Хто міг ие бути? Мамин чи татів вірний приятель? (Вавілонська вежа).

Окремі поезії в прозі Ірини Вільде насичені таким засобом інтимізації як парцеляція. Авторка використовує ії для передачі напруги 
переживань ліричної героїні, створення динаміки викладу основної думки напр.: Ти маєш тридиять літ, пробіль, як з каменя вирізьблений, $і . .$. томуя боюсь тієї незнайомої у веснянім капелюшку. Тієї неминучої... Тієї майбутньої... (Ти); Одне-однісіньке пополудні на тиждень мати для себе. Виключно для себе..., Цілком так: рожеві місяці закоханості в свого нареченого заступили медові місяці шлюбу. На жаль, тільки місяці, Нарешті - сама. Втомлена , паде на канапу. Нарешті - спокій (Щастя).

Поезія в прозі «Одного весняного вечора» найбільш насичена парцеляцією, що посилює напруженість думки, передає емоції матері, яка переживає за долю доньки, напр.: Ірка в ией час має бути в музичному інституті. Байдуже. Марія хоче знати, в якому настрої вийшла з дому та шалена дівчина. Мусить знати, Добре, добре... Про все ие вона подумає ще иієї ночі, але зараз мусить бачити іі. Ніяких докорів, ніяких суворих запитань. Тільки побачити, Марія чує, як він стоїь біля хвіртки і проводжає ії очима. Потім іде. Дуже поволі, Природний порядок речей: ніяких непередбачених подій, відхиень, химер, ілюзій. Простим шляхом аж до мети. Так найкращзе.

\section{Висновки}

Таким чином, проаналізовані поезії в прозі Ірини Вільде дають підставу стверджувати, що авторка використовує багату палітру мовних засобів інтимізації, найбільш виразними і поширеними $є$ риторичні питання, звертання, еліптичні речення, імператив, парцеляція. Ці засоби допомагають досягнути основної мети - відкритої дружньої розмови авторки з читачем, створюючи доброзичливу відверту атмосферу. Обсяг статті не дозволяє висвітлити всі мовні засоби інтимізації в поезіях в прозі Ірини Вільде, тому це стане перспективою подальших досліджень.

\section{ЛІТЕРАТУРА}

1. Булаховський Л. А. Мовні засоби інтимізації в поезії Т. Шевченка. Вибрані праці: в 5 т. Київ: Наукова думка, 1977. Т. 2. С. 573-593. 2. Вільде І. Незбагненне серце. Львів: Каменяр, 1990. 256 с. 3. Загнітко А. П. Словник сучасної лінгвістики: поняття і терміни: у 4 т. Донецьк: ДонНУ, 2012. Т. 1. 386 с. 4. Зайцева Ю. Г. Інтимізація як мовознавча проблема. Лінгвістичні дослідження. Харків: ХНПУ ім. Г. С. Сковороди, 2015. Вип.39. С. 140-145. 5. Зайцева Ю. Г. Демінутиви як засоби інтимізації в жанрі української поезії в прозі. Мова. Наука. Культура - 2015: збірник наукових праць за матеріалами міждисциплінарної конференції, присвяченої 85-річчю Харківського 
національного технічного університету сільського господарства імені П. Василенка (Харків, 10 червня 2015 р.). Харків: Міськдрук, 2015. С. 222-229. 6. Палійчук А. Л. Наративний код інтимізації (на матеріалах англомовного художнього дискурсу): дис. ...канд. філол. наук: 10.02.04. Луцьк, 2011. 7. Трофимова Э. А. Синтаксические конструкции английской разговорной речи. Ростов: Изд-во Ростовск. ун-та 1981. 160 с. 8. Фурист Н. П. Лінгвокультурні особливості інтимізації в англійських та українських фольклорних текстах (на матеріалі казок про тварин): автореф. дис. ...канд. філол. наук:10.02.17. Київ, 2011. 24 с.

\section{REFERENCES}

1. Bulakhovskyi, L. A. (1977). Movni zasoby intymizatsii v poezii T. Shevchenka [Linguistic means of intimization in T. Shevchenko's poetry]. Kyiv: Naukova dumka [in Ukrainian]. 2. Wilde, I. (1990). Nezbahnene sertse [Incomprehensible Heart]. Lviv: Kameniar [in Ukrainian]. 3. Zahnitko, A. P. (2012). Slovnyk suchasnoi linhvistyky: poniattia i terminy [A Dictionary of Modern Linguistics: Concepts and Terms]. Donetsk: DonNU [in Ukrainian]. 4. Zaitseva, Yu. H. (2015). Intymizatsiia yak movoznavcha problema [Intimization as a linguistic problem]. Linhvistychni doslidzhennia - Linguistic research, 39, 140-145. Kharkiv: KhNPU im. H. S. Skovorody [in Ukrainian]. 5. Zaitseva, Yu. H. (2015). Deminutydy yak zasoby intymizatsii $\mathrm{v}$ zhanri ukrainskoi poezii v prozi [Diminutives as means of intimization in the genre of Ukrainian poetry in prose]. Mova. Nauka. Kultura-Language. Science. Culture: The collection of scientific papers based on input from the interdisciplinary conference dedicated to the 85th anniversary of Kharkiv National Technical University of Agriculture named after P. Vasylenko . (pp. 222-229). Kharkiv: Miskdruk [in Ukrainian]. 6. Paliichuk, A. L. (2011). Naratyvnyi kod intymizatsii (na materialakh anhlomovnoyo khudozhnoyo dyskursu) [ Narrative code of intimization (in English artistic discourse)]. Candidate's thesis. Lutsk: VNU im. Lesi Ukrainky [in Ukrainian]. 7. Trofimova, E. A. (1981). Sintaksicheskie konstruktsii anhliiskoi razhovornoi rechi [The syntactic structures of spoken English language]. Rostov: RU [in Russian]. 8. Furyst, N. P. (2011). Linhvistychni osoblyvosti intymizatsii v anyliiskykh ta ukrainskykh testacy (na materiali kazok pro tvaryn) [The linguistic and cultural features of the intimization of English and Ukrainian folklore texts (based on the animal tales)]. Extended abstract of candidate's thesis. Kyiv: NPU im. M. P. Drahomanova [in Ukrainian].

Зайцева Юлія Георгіївна - аспірант кафедри української мови, Харківський національний педагогічний університет імені Г. С. Сковороди. Вул. Валентинівська, 2, Харків, 61168, Україна.

Tel: +38-068-903-34-34

E-mail: julia.zaitseva2015@gmail.com

http://orcid.org/0000-0003-4269-5552

Zaitseva Yulia Heorhiivna - Postgraduate Student, Ukrainian Language Department, H.S. Skovoroda Kharkiv National Pedagogical University. Valentynivska Str., 2, Kharkiv, 61168, Ukraine. 